\title{
Greenhouse cultivation of fruit crops with special reference to India: An overview
}

\author{
Rajkumar Jat \\ Department of Horticulture, College of Agriculture, G. B. Pant University of Agriculture \\ and Technology, Pantnagar, U.S. Nagar-263145 (Uttarakhand), India \\ Vijay P. Singh* \\ Department of Horticulture, College of Agriculture, G. B. Pant University of Agriculture \\ and Technology, Pantnagar, U.S. Nagar-263145 (Uttarakhand), India \\ Virendra Kumar \\ School of Agriculture, Uttarakhand Open University, Haldwani- 263139, Nainital (Uttarakhand) \\ *Corresponding author. Email: hortvp@gmail.com
}

\begin{abstract}
India is facing various challenges in fruit cultivation viz., climate change, increasing pressure on natural resources, decreasing land tenure with the ever-increasing population. Besides this, the demand for quality fruit is also on the rise as people are now more aware of a nutritious and healthy diet. The quality with higher production is difficult with the traditional system of cultivation and requires a more scientific approach in cultivation. Greenhouse cultivation technology can enhance quality and quantity both. This technology is required to convert some portion of the present 6.5 million ha of the fruit-growing area to increase national productivity and product quality. The purpose of greenhouse cultivation is to grow crops by altering the micro-environment surrounding the crop so that the plant performs maximum to its genetic potential. It also increases the yield, improves the quality and stability of production and makes commodities available when there is no outdoor production. China is the world leader in greenhouse fruit production with the largest area under this technology. In India, greenhouse fruit cultivation is in its infancy as the only strawberry is commercially being grown under greenhouses. However, in fluctuating environmental conditions and losses in fruit crops due to various biotic and abiotic stresses, protecting the fruit crops for the off-season, quality and higher production will be a necessity in future. Keeping in view the low productivity of fruit crops in India and future needs of round the year quality production, an overview of work and cultivation scenario on this aspect is discussed in this paper.
\end{abstract}

Keywords: Economic feasibility, Fruit crops, Greenhouse, Quality, Yield

\section{Article Info}

https://doi.org/10.31018/

jans.vi.2276

Received: May 8, 2020

Revised: June 4, 2020

Accepted: June 10, 2020

\section{How to Cite}

Jat, R. et al. (2020). Greenhouse cultivation of fruit crops with special reference to India: An overview. Journal of Applied and Natural Science, 12(2): 252 - 260 https://doi.org/10.31018/ jans.vi.2276

\section{INTRODUCTION}

India is the second-largest producer of fruits (97.55 million MT) obtained from 6.50 million ha area, productivity being $14.96 \mathrm{MT} / \mathrm{ha}$ (NHB database, 2018) contributing about 10.5 per cent share in global fruit production. However, the productivity of different fruit crops in India is quite low compared to other leading countries, as shown in Table 1. Fruits have a direct impact on GDP of the country. For example, banana crop alone accounts for 2.8 per cent of agricultural GDP. The overall fruit productivity is as high as 23.39 ton/ha of Tamil Nadu, whereas it's as low as 3.75 ton/ ha of Uttarakhand as shown in Table 2. This puts forth a question of why the difference and how to increase productivity? The answer can be the states having a higher area under protected cultivation technologies are having higher productivity. A burgeoning population, fragmentation of landholdings, depletion and erosion of natural resources are all adversely affecting agricultural productivity (Singh et al., 2017). With the rapid rise in demand for fruits leading to their high prices, technological innovations are inevitable, which can improve their productivity and ensure off-season supply. One such technology with considerable potential is 'greenhouse cultivation,' which involves growing such crops under the conditions of the regulated climate. The purpose of greenhouse cultivation is to grow crops by altering the micro-environment surrounding the crop so that the plant performs maximum to its genetic potential. The advantages of this system include easier cultivation (e.g. irrigation, weed control, pest management, harvesting, etc.), reduced yield loss due to environmental factors, working in all weather conditions, improved 
Table 1. Productivity of different fruit crops (Source: NHB, 2018).

\begin{tabular}{lllllll}
\hline Country & Apple & Banana & Grape & $\begin{array}{l}\text { Mango \& } \\
\text { guava }\end{array}$ & Orange & Papaya \\
\hline China & 18.6 & 30.98 & 17.6 & 8.1 & 16.9 & - \\
USA & 35.3 & - & 17.3 & - & 23.1 & - \\
France & 36.7 & - & 8.2 & - & - & - \\
Italy & 43.7 & - & 12.28 & - & 17.7 & - \\
Brazil & - & 14.4 & - & 17.9 & - & 46.9 \\
Indonesia & - & 50.0 & - & 13.0 & - & 90.6 \\
India & 9.1 & 34.43 & 21.2 & 8.3 & 12.9 & 42.8 \\
\hline
\end{tabular}

marketable fruit, consistent high yield, and, most importantly, early growth and higher profitability (Singh et al., 2013). It also increases the yield, improves the quality and stability of production and makes commodities available when there is no outdoor production. Its primary emphasis is on the production of high-value horticultural crops. It provides control over wind velocities, moisture, temperature, mineral nutrients etc.

China is the world leader in greenhouse fruit production with the largest area under this technology. Various kinds of fruit, such as strawberry (Fragaria $\times$ ananassa), grape (Vitis vinifera), peach (Prunus persica), apricot (Prunus armeniaca), cherry (Prunus avium), plum (Prunus domestica) and citrus (Citrus spp.) have proved to be successful for protected cultivation worldwide. Three commercially important single-stemmed crops - banana (Musa spp.), pineapple (Ananas comosus) and papaya (Carica papaya) - are cultivated under greenhouse in the subtropics. Greenhouse mango (Mangifera indica) cultivation is mainly done in Japan; however, Israel also started its commercial cultivation. In India greenhouse fruit cultivation is in its infancy as the only strawberry is commercially being grown under greenhouses. However, in fluctuating environmental conditions and losses in fruit crops due to various biotic and abiotic stresses, providing protection to the fruit crops for the off -season, quality and higher production will be a necessity in future. Keeping in view the low productivity of fruit crops in India and future need of round the year quality production, a systematic review on work and cultivation scenario worldwide on this aspect is very much desired. Hence appropriate findings on greenhouse fruit cultivation have been discussed in this paper.

\section{GREENHOUSE}

Green house is a constructed structure covered with transparent or translucent material in which the plants are grown under-regulated or partly controlled environmental conditions resulting in yields that are higher than in open conditions (Ghosh, 2009). In general, greenhouse cultivation may be considered as a protected cultivation technology that improves crop maturity, increases yield, improves product quality and, in some cases, reduc- es pesticide usage. A major issue with modern greenhouse designs is the accumulation of heat inside the covered structures, which must either be removed or neutralized by energy-intensive refrigeration facilities. This problem was resolved by the design of naturally ventilated greenhouses where the temperature can be kept at the optimal level without any energy usage.

Principle of greenhouse: The greenhouse is generally covered by transparent material such as polyethylene or glass or polycarbonate. Significant fractions of the incoming solar radiation are absorbed by plants and objects on earth. Such structures in effect emit thermal radiations of long waves for which the cladding material has low transparency. Thus, inside the polyhouse longwave, thermal radiation is trapped, which raises the temperature inside. This is known as the greenhouse effect. Since this temperature rises within polyhouses, it is possible to grow off-season crops in a cold climate. During the summer months, the temperature is reduced to low by providing cooling equipment in polyhouses. Depending on transparency, the greenhouse cover allows solar radiation to pass through but traps thermal radiation emitted by the objects within, thus increasing the inside temperature termed as greenhouse effect (Ghosh, 2009).

Types of greenhouse based on the cost of installation: The types of greenhouse based on the cost of installation (Singh, 2005) are given as follows:

Low-cost polyhouse/greenhouse: The 700 gauge thick polythene sheet is supported by bamboo ropes and nails. The temperature inside the

Table 2. Productivity of different states (Source: NHB, 2018).

\begin{tabular}{ll}
\hline State & Productivity (t/ha) \\
\hline Andhra Pradesh & 23.39 \\
Gujarat & 21.29 \\
Punjab & 21.06 \\
Madhya Pradesh & 20.95 \\
Tamil Nadu & 19.49 \\
Karnataka & 16.52 \\
Uttarakhand & 3.75 \\
\hline
\end{tabular}


greenhouse is $6-10^{\circ} \mathrm{C}$ higher than the outside temperature.

Medium cost greenhouse: It is more costly than low tech greenhouse. Galvanised iron (GI) pipes are used in Quonset-shaped ployhouses frame. The thickness of stabilized polythene, single coated Ultra Violet (UV), is 800 gauges. The exhaust fan is controlled thermostatically. Frames and glazing materials each have a life span of 20 years and 2 years.

Hi-tech greenhouse: The frame is made of aluminium or iron. Designs are dome or cone-shaped. These are highly durable, 5-6 times more costly, growing media used in greenhouses of this sort are peat, perlite, solarite, vermiculite, rock wool. Coconut fibres and rice husks are used as growing media in India since these materials are cheaper. Fertigation and spraying of pesticides are performed by fogging unit.

\section{Effect of greenhouse on micro-climatic conditions}

Mango: Juntamanee (2013) investigated the effect of plastic roof on canopy microclimate and found that irradiance level under plastic roof exceeded $1600 \mu \mathrm{mol}$ PPF m $\mathrm{m}^{-2} \mathrm{~s}^{-1}$, which was $26 \%$ lower than natural condition but considered as enough for net photosynthesis (Pn) of mangoes (Mangifera indica) whereas, in both day time and night, the plastic roof did not lower air temperature. The relative humidity measured during the day under a plastic roof was lower than that under natural conditions, while the growing conditions did not affect the relative humidity of the night.

Medany et al. (2009) conducted a study on the suitability of white greenhouse net cover for growth of mango (Mangifera indica. L.) cv. Keitt and found that maximum temperature tended to be lower under the nets $\left(2^{\circ} \mathrm{C}\right)$, due to the interception of radiation which is greater than the gain of temperature caused by the use of nets due to their role in the interception of air circulation or the greenhouse effect. Bigger differences were recorded in the growing seasons. Minimum temperatures tended to be lower in control by $1^{\circ} \mathrm{C}$ than in the nets because of the greenhouse effect and the low radiation at this time of the day. Average relative humidity increased by the use of the white net by 4-8 per cent compared with an open field. These results are correlated with Iglesias and Alegre (2006), who reported a 2-6\% increase in humidity associated with the use of nets in 'Mondial Gala' apples (Malus domestica).

Banana: The difference in greenhouse temperature above and below the canopy was as high as 9 ${ }^{\circ} \mathrm{C}$. With regard to the cooling of the greenhouse during the summer, the best effect was achieved when the ventilation was opened, and the cooling system turned on during the hottest part of the day. As a result of this procedure, the inside temperature below the canopy level was reduced by 8
${ }^{\circ} \mathrm{C}$ compared to the lower canopy temperature outside the greenhouse. The relative humidity was also increased by turning on the overhead cooling system up to 18 per cent (Ectsiin et al., 1998).

Grape: Jiang et al. (2013) reported that impermeable plastics covering grapevine rows increased air temperature and decreased photosynthetic radiation and wind velocity. The coverage interfered with the efficiency of incoming solar radiation, especially by decreasing ultraviolet band irradiance and also by the ratio of the red and farred bands irradiance. The temperature and relative humidity in the canopy of Cabernet Gernischet grape (Vitis vinifera) under rain-shelter cultivation were elevated compared to open-field cultivation, while the illumination intensity was declined.

\section{Effect of greenhouse cultivation on vegetative} growth parameters

Mango: Medany et al. (2009) investigated the effect of white net cover on the vegetative growth of mango trees and found that plant height, number of leaves, number of branches per plant and main stem diameter per plant were significantly higher in the white net covered greenhouse compared to open field conditions in both seasons. Increased vegetative growth, such as plant height, number of leaves and stem diameter per plant under greenhouse conditions, may be attributed to favourable weather conditions, i.e. increased relative humidity, lower maximum temperature and light irradiance, higher minimum temperature and, finally, lower wind speed compared to open field conditions (Iglesias and Alegre, 2006). The height and diameter of the tree canopy of cultivar Zill grown under outdoor conditions were 1.5 and $1.8 \mathrm{~m}$ respectively, $1.02-1.68 \mathrm{~m}$ and $0.7-1.5 \mathrm{~m}$ for Keitt and Haden under the net. In the greenhouse tree height and tree, diameter ranged between 1.34-2.36 $\mathrm{m}$ and 1.15-1.86 m, respectively, for the twelve cultivars studied (Lionakis and Loxou, 1997).

Banana: Gubbuk and Pekmezci (2004) revealed that in 'Dwarf Cavendish' banana (Musa spp. AAA) the average pseudostem circumference was 68.5 $\mathrm{cm}$ in the open field and $78.3 \mathrm{~cm}$ in protected cultivation. Mean height of the pseudostem was $1.7 \mathrm{~m}$ in the open field and $1.8 \mathrm{~m}$ in protected cultivation. In protected cultivation, the total number of leaves was found to be higher (28.2) than in an open field (20.8). Similar results were also reported by Ectsiin et al. (1998). They found that the plants were 34 per cent taller and the pseudostem circumference was 4 per cent higher when flowering inside the greenhouse compared to the plants grown outside. Peach: Vukovic et al. (2017) assessed that peach (Prunus persica) and nectarine (Prunus persica var. nucipersica) trees had considerably higher leaf surfaces under the red net $\left(37.82 \pm 5.41\right.$ and $40.72 \pm 7.87 \mathrm{~cm}^{2}$, respectively) 
than those under control $(23.85 \pm 6.16$ and $26.14 \pm 4.04 \mathrm{~cm}^{2}$, respectively). Similarily, Giaccone et al. (2012) reported that the mean leaf size of nectarine trees was higher under the red net than under white net. Schtenni et al. (2011) reported that trunk area and shoot length (6.8 $\mathrm{cm}^{2}$ and $30.5 \mathrm{~cm}$, respectively) were found higher in red net followed by the blue net as compared with open field conditions. This is because the red net, distinguished by lower ratios of $R$ / FR and $\mathrm{B} / \mathrm{FR}$ than the normal outdoor radiation parameters, stimulated vegetative behaviour by directly influencing photomorphogenetic receptors (Young et al., 1994). It can, therefore, be inferred that the red photoselective net has a positive effect on the surface of the leaf, which can further improve the photosynthetic ability.

Custard apple: Higuchi et al. (2001) evaluated shading responses of Cherimoya (Annona cherimola Mill.) leaf morphology and shoot growth at 3 different shading levels under plastic house conditions. Shoot length and number of leaves at light shading (64 per cent sunlight) were greater than at the other shading levels. The length of the inter-node and the specific length of the stem were increased with shade. The diameter of the stem and the dry weight of the leaf and stem were higher in light shading conditions. Although dry tissue weights were suppressed under deep shading conditions (10 per cent of sunlight), dry stem weight was less affected by shading than dry leaf weight. The thinner and larger leaves developed under the heavier shade of the surroundings. A heavier shade increased the single leaf area while the total leaf area per shoot was reduced. The specific area of the leaf increased as the shading level increased, indicating that the thicker shade of the leaves reduced the thickness of the leaf.

Grape: Based on the average of 2 years, the shoot elongation of plants in protected cultivation was greater than that of plants grown in open fields. In addition, "Uslu" was the fastest-growing compared to "Yalova incisi" and "Perlette incisi" cultivar in both open field and protected production based on the shoot measurement in the last period. The development of the shoots of the "Yalova incisi" and "Perlette incisi" cultivars in the open field were found to be the lowest in the field (Kamiloglu et al., 2011).

Strawberry: Pandey et al. (2015) evaluated the effect of different growing environment on morphological characters of strawberry (Fragaria $x$ ananassa) cv. Winter Dawn. The crop grown in a naturally ventilated polyhouse reported maximum crown height $(26.46 \mathrm{~cm})$, a higher number of leaves (72.55) per plant and plant spread (E-W: $48.05 \mathrm{~cm}$; N-S: $44.06 \mathrm{~cm}$ ), while strawberry plants grown in Fan pad system greenhouse reported maximum petiole length $(15.35 \mathrm{~cm})$, whereas minimum $(7.80 \mathrm{~cm})$ were observed in plants grown in agro-shade net. However, the plant weight on fresh weight $(115.00 \mathrm{~g})$ basis was maximum under naturally ventilated polyhouse while it was improved in open field conditions on a dry weight basis $(30.88 \mathrm{~g})$.

Effect of greenhouse cultivation on flowering: Banana: The period from shooting to harvest was 41.4 days shorter in protected cultivation (Gubbuk and Pekmezci, 2004). However, Plants grown in the greenhouse were found to flower 6.9-7.0 months after planting, but plants grown outside flowering started 9.2-10.10 months after plantation. But long time (5.3-6.5 months) was taken to harvest in greenhouse conditions for flowering, while day from planting to fruit harvest was lowest (12.7-13.4 months) in greenhouse bananas whereas 4.4-5.3 months from flowering to harvest and 14.5-14.9 months from planting to harvest under open conditions (Ectsiin et al., 1998).

Grape: Kamiloglu et al. (2011) reported that the phenological periods were observed earlier in the protected plants than in those grown in the open field, the vines under cover reached bud break 9 days early, full bloom 14 days early, verasion 16 days early and maturity 17 days early. These findings are correlated with the finding of Coban (2007) who reported that plastic covering advanced flowering 31-33 days in Cardinal, 25-27 days in Yalova Incisi and 35-39 days in round seedless, and verasion 28-30 days in Cardinal 23 days in Yalova Incisi and 31 days in round seedless which is due to higher air temperatures under plastic covers.

Papaya: Papaya cultivar Pusa Nanha showed early flower initiation (64.67 days), the higher number of the leaf at flowering (18.33), petiole length (84.32), long fruiting zone (171.46) and fruit set $(46.23 \%)$ as compared to open field conditions (Prakash et al., 2015). Similarly, greenhouse -grown plants reported early flower initiation (84.69 days), the highest number of flowers produced per plant (48.88) with a maximum fruit set $(74.38 \%)$. Whereas in open field plants, late flower production (95.69 days) and minimum fruit set (45.98 per cent) were recorded (Reddy and Gowda, 2014). This may be attributed to increased hormonal metabolism and photosynthesis in the plant due to the presence of more suitable modified environment in the greenhouse and also due to early flowering, increased fruit setting and extended harvesting periods which are controlled by environment factors in protected cultivation.

Loquat: An experiment conducted in loquat (Eriobotrya japonica) using high-density planting $(3 \mathrm{~m} \times 3 \mathrm{~m})$ and protected cultivation resulted that protected cultivation caused earliness of 13-20 days when compared to an open field (Polat et al., 2005). Lorente et al. (2003) also observed that cultivation in a plastic-covered greenhouse result- 
ed in early harvesting in cv. Algerie 10-12 and cv. Redonet six days ago in Alicante, Spain.

\section{Effect of greenhouse cultivation on yield}

Mango: Medany et al. (2009) observed a higher yield of mango when using a white net compared to open field conditions. The reduction of radiation is responsible for the down-regulation of the leaves' photosynthetic potential and, as a result, a lower saturated photosynthetic light intensity compared to the control (Gindaba and Wand, 2007). Lionakis and Loxou (1997) assessed the yield of twelve mango cultivars grown in greenhouse, nethouse and outdoor conditions. The various cultivars produced $5.34-31.46 \mathrm{~kg}$ of fruit per plant in the greenhouse. In the greenhouse, the cultivar Zill produced $12.68 \mathrm{~kg}$ per tree and in outdoor conditions $1.50 \mathrm{~kg}$ per tree. The production of Haden and Keitt cultivars under the net was $8.51 \mathrm{~kg}$ per tree and $5.25 \mathrm{~kg}$ per tree, respectively, while the production was $18.25 \mathrm{~kg}$ per tree and $31.46 \mathrm{~kg}$ per tree in the greenhouse.

Banana: Darini (2016) investigated the yield of five banana cultivars viz. Harychal, Dwarf Cavendish, Valery, Chains Cavendish and Grand Nain. The maximum and minimum yield was observed in Harychal and Grand Nain with 30.26 and 25.34 ton/ha per harvesting, respectively. According to these findings, Harychal, Chains Cavendish and Dwarf Cavendish cultivars are recommended for cultivation in the rejoins greenhouses with existing structures. Gubbuk and Pekmezci (2004) reported that the finger count, finger diameter, and finger length were 185 fingers/bunch, $8.3 \mathrm{~cm}$, and $16.6 \mathrm{~cm}$, respectively, compared to 251 fingers/bunch, $10.9 \mathrm{~cm}$, and $21.0 \mathrm{~cm}$, respectively, in open-field and protected cultivation. In protected cultivation, the weight of the bunch was $14 \mathrm{~kg}$ heavier compared to the open field. The quantitative parameters clearly show that bananas grown in protected fields are superior to those grown in open-field cultivation, with an increase in yield of 53\%. Gubbuk et al. (2004) also revealed that growing greenhouse (under plastic) bananas were found to be superior to open-field cultivation with yield increases of 19 to 28 per cent depending on the crop. Similar results were also obtained from Eckstein et al. (1998) and Galan Sauco et al. (1998). The yield variations were 28 per cent and $>20$ per cent respectively between greenhouse cultivation and open-field cultivation.

Papaya: Kaur and Kaur (2017) evaluated the performance of papaya (Carica papaya) cv. Red lady 786 under various growing conditions. The plants under net house showed an increase in fruit length $(22.68 \mathrm{~cm})$, breadth $(11.93 \mathrm{~cm})$, weight $(874.32 \mathrm{~g})$ and fruit volume $(895.16 \mathrm{cc})$. Similarly, higher fruit yield was obtained from the plants under the net house (35.15 kg/plant) as compared to an open field (21.87 $\mathrm{kg} /$ plant). The increased yield in the net house may be due to the extent of the incidence of papaya ringspot virus
(PRSV), continuous and healthy growth, and a high number of fruits and enhanced fruiting zones. Prakash et al. (2015) also compared yield traits in papaya variety Pusa Nanha under polyhouse and open field conditions. The evaluation of papaya under polyhouse showed higher fruit yield (34.56 kg/plant) as compared to open field conditions. Tyagi et al. (2015) evaluated five papaya varieties viz. Surya, Madhu, Arka Prabhath, Pusa Dwarf and Red lady 786 under poly nethouse. Among all five varieties, the highest yield $(38.84 \mathrm{~kg})$ and best quality fruit traits in terms of fruit weight $(841.67 \mathrm{~g})$ were found in variety Red Lady 786. Gunes and Gubbuk (2011) investigated yield and fruit quality of three papaya cultivars grown under greenhouse conditions. Maximum fruit weight $(460.0 \mathrm{~g})$, width $(11.7 \mathrm{~cm})$, length $(16.7 \mathrm{~cm})$ and yield $(28.3 \mathrm{~kg} / \mathrm{plant})$ were obtained in Sel-42 and followed by SS-45 whereas $\mathrm{BH}-65$ produced the smallest fruits with lowest fruit weight $(250.0 \mathrm{~g})$, width $(9.7 \mathrm{~cm})$ and length $(13.3 \mathrm{~cm})$ and yield $(7.8 \mathrm{~kg} / \mathrm{plant})$. Hence cultivars Sel-42 and SS-45 could be recommended for greenhouse cultivation under a Mediterranean climate in Turkey. These findings are correlated with the reports of Reddy and Gowda (2014) and Allan (2007) with 'Honey Gold' papaya from South Africa.

Peach: Vukovic et al. (2017) evaluated that peach trees under red net had higher yield $(1130.00 \pm 340.00 \mathrm{~g})$ and higher fruit mass $(163.73 \pm 36.42 \mathrm{~g})$ than in control $(710.00 \pm 300.00$ $\mathrm{g}, 135.84 \pm 37.37 \mathrm{~g}$ respectively). These findings are in agreement with Schettini (2011), who also reported that peach trees under red net had a significantly higher yield than trees in control. However, the fruit yield of nectarine 'Laura' was not significantly affected by the type of anti-hail net (Giaccone et al., 2012).

Grape: Novella et al. (2000) investigated the effects of different plastic sheet coverings on yield and quality performance of table grape cv. matilde. LDPE + EVA covering increased yield per vine $(+21 \%$ over the open field). Whereas, bunch and berry mass were found greatest under LDPE + EVA covering (775.37 g and $8.12 \mathrm{~g}$, respectively) and progressively decreased under LDPE + HDPE covering ( -6 and -8 per cent, respectively) and in the open field (-12 and -22 per cent, respectively).

Strawberry: Menzel et al. (2016) examined the effect of growing system and cultivar and breeding lines on the performance of plants and reported that Marketable yields were 38 per cent higher in tunnel-growing plants than in outdoor-growing plants in 2012 (991 vs. $720 \mathrm{~g}$ ) and 24 per cent higher in 2013 (594 vs. $479 \mathrm{~g}$ ) mainly due to less rainfall. Regarding yield attributing characteristics, the higher number of fruits (29.00) and fruit yield (242.77 g per plant) was found in naturally 
ventilated polyhouse (Pandey et al., 2015). Larson et al. (2009) also evaluated yield performance for 'Camarosa' and 'Ventana' cultivars using open field (OF) and protected culture (PC, i.e., Spanish tunnel) production. PC resulted in increased early season yield, and increased total yield and fruit quality compared to standard outdoor production due to absence of dew, rain, hail and frost and fruit produced with PC can be harvested even regardless of weather conditions.

Raspberry: The quality and yield of raspberry (Rubus spp.) increased in high tunnels (9630lb/ acre) compared to $5082 \mathrm{lb} / a c r e$ in an open condition. Additionally, the fruit size was slightly greater in this study, with an overall average of $2.8 \mathrm{~g}$ per berry compared to $1.7 \mathrm{~g}$ in the first year of the outside trial (Weber et al., 2004).

\section{Effect of greenhouse cultivation on quality parameters}

Banana: Junior et al. (2010) evaluated the quality of the fruit and nutrient content of Cavendish banana cultivars produced under four greenhouse covers and found that the quality of the fruit was not influenced by covers or cultivars and that there were also no significant differences between openair and greenhouse cultivation. Gubbuk and Pekmezci (2004) also observed that the circumference of the bunch stalk, as well as the number of hands, also varied considerably; $22.2 \mathrm{~cm}$ in an open field and $25.4 \mathrm{~cm}$ in protected cultivation for the circumference of the bunch stalk and $10.6 \mathrm{~cm}$ in an open field and $12.9 \mathrm{~cm}$ in protected cultivation for the number of hands.

Papaya: The physical and chemical composition of papaya fruit, i.e. fruit firmness $\left(1.97 \mathrm{~kg} \mathrm{~cm}^{-2}\right)$ total soluble solids $\left(11.3^{\circ} \mathrm{B}\right)$ and ascorbic acid (75.26 mg/ $100 \mathrm{~g}$ pulp) has improved under polyhouse conditions over open-field production (Prakash et al., 2015). Reddy and Gowda (2014) were observed higher TSS $\left(13.92^{\circ} \mathrm{Brix}\right)$, total sugars $(12.64 \%)$, reducing sugar $(9.53 \%)$, nonreducing sugar (3.11\%), sugar/acid ratio (105.33), carotene content $(2.42 \mathrm{mg} / 100 \mathrm{~g})$ with minimum titratable acidity $(0.12 \%)$ and ascorbic acid $(96.18$ $\mathrm{mg} / 100 \mathrm{~g}$ pulp) under polyhouse conditions. This could be due to the presence of a more suitable climate, i.e. temperature, light intensity and relative humidity, which in turn influenced the development of more photosynthates, more leaves and leaf areas in addition to enhanced growth, traits that could lead to better transfer to produce sweeter fruit with less acidity.

Peach: Schtenni et al. (2011) stated that different coloured nets had a positive impact on skin percentage over colour. The fruits harvested from the open-field trees were 27.4 per cent overcoloured, while the fruits harvested from the trees grown under the red and the blue nets were 59.3 per cent and 52.3 per cent respectively. Negative effects on the soluble concentration of solids and titratable acidity were observed.

Grape: Kamiloglu et al. (2011) observed the highest cluster weight and width values in Ergin cekirdeksizi (322.42 $\mathrm{g}$ and $10.27 \mathrm{~cm}$, respectively) and the longest cluster length was observed in Uslu (22.39 cm). Higher TSS (14.82 \%) were recorded in protected cultivation and $14.68 \%$ in open field cultivation. The $\mathrm{pH}$ value for the open field (3.08) and protected cultivation was found to be approximately identical (3.09). In protected cultivation, the acid content was higher $(0.74$ per cent) than in the open field ( 0.65 per cent). This may be due to the fact that the maturity index of protected cultivation (20.62) was lower than that of open field cultivation (23.21). However, Vool et al. (2013) recorded total soluble solids ranges from 24.1-25.4 oB but under the open condition it ranged from $17.9-21.8 \mathrm{oB}$, the lowest titratable acidity $(1.2-1.2 \mathrm{~g} / 100 \mathrm{~g})$ was noticed in protected cultivation of grape cultivars (Hasanski Sladki and Zilga respectively) and maximum TA (1.5-1.6 $\mathrm{g} / 100 \mathrm{~g}$ ) noticed in open condition, highest total phenolics and anthocyanins $(540$ and 480 $\mathrm{mg} / 100 \mathrm{~g}$ and 160 and $112 \mathrm{mg} / 100 \mathrm{~g}$ ) was noticed in protected cultivation of grape cultivars (Hasanski Sladki and Zilga respectively) whereas the lowest total phenolics and anthocyanins (326 and $222 \mathrm{mg} / 100 \mathrm{~g}$ and 133 and $64 \mathrm{mg} / 100 \mathrm{~g}$ ) noticed in open condition.

Mango: Akinaga and Hasbullah (2002) investigated average dimensions of five mango cultivars under plastic greenhouse in Nago, Okinawa. Average fruit weight ranges from 420-900 g which was highest in cultivar keitt and lowest in sensation. Whereas, total soluble solids was found highest in Haden (15.2 ${ }^{\circ} \mathrm{B}$ ) and lowest in cultivar Irwin.

Strawberry: Pandey et al. (2015) investigated the effect of different growing environments on fruit quality characteristics of strawberry cv. Winter Dawn. Maximum fruit length $(47.72 \mathrm{~mm})$, fruit width $(42.59 \mathrm{~mm})$, length: diameter ratio, fruit weight (on fresh weight and dry weight basis) $(26.85 \mathrm{~g}, 2.08 \mathrm{~g})$ was recorded in plants grown under open field conditions than growing environment while minimum fruit length, length: diameter ratio (1.03) was observed in Fan pad system greenhouses and least fruit width and fruit weight were found in Agro shade net condition. However, Strawberry grown in open field condition was better with respect to fruit juice $(96.10 \%)$, total soluble solids $\left(7.30{ }^{\circ} \mathrm{B}\right)$, total sugars $(5.15 \%)$ and sensory scores (8.35). Beckmann et al. (2006) explained as high sugar content in the fruits produced in the field might be due to the greater light intensity and greater photosynthetic plant activity in this crop environment.

\section{Economic feasibility}

Mango: Mohamed and Medany (2015) evaluated the efficiency of production and the revenue of two different systems of cultivation of Keitt mango 
(Mangifera indica L.) and navel orange (Citrus sinensis L.) during the cultivation period 2007 2013. The results showed that the average yield of navel orange under-screen net was 18.9 tons / feddan $\left(4200 \mathrm{~m}^{2}\right)$ compared to 12.3 tons / feddan in an open field during 2007-13. While, net annual return in the screen net was 9940 L.E. per feddan, while net open field return was 6451 L.E per feddan. Whereas the average annual yield under screen net for Keitt mango during 2007-2013 was 4,725 tons / feddan and 2.3 tons / feddan for the open area. In addition, the annual net return in the screen net was 27467 L.E per feddan, while the average open field return was 10843 L.E per feddan. Medany et al. (2009) also evaluated efficiency of production of mango trees under white net and results revealed that two years compared with control treatment, the white net was superior in fruiting, with a total gain of $19160 \mathrm{~L}$. E. during the first two years after cultivation (Not taking into account production costs i.e. labour, supplies, irrigation, etc.). In the case of using a white net cover, the gain increased compared to the control currently being used in Egypt's main fruit production areas.

\section{Effect of greenhouse cultivation on disease and insect incidence}

Grape: Sen et al. (2016) evaluated the effects of different shading ratio $(0,35$, and $75 \%)$ and covering material including Polypropylene Crossstitch (PC), Life Pack (LP) and Mogul (MG)) on "Sultana Seedless" table grape quality, decay incidence and storability. The occurrence of postharvest decay was not observed in all treatments after 60 days of storage, but decay and stem browning occurred in unshaded and S35+LP treatments at the end of 90 days. Jiang et al. (2013) reported that grapevines grown in the open field had serious diseases and increased their severity to the fourth grade (the area of infected leaves is above $75 \%$ ). Infected plant diseases included primarily downy mildew on grape leaves, anthracnose and white rot in grape berries. In the hot and rainy season, certain diseases could proliferate and spread. In both vintages, leaf disease (incidence of leaf disease, degree of defoliation, and index of disease) and fruit disease (incidence of cluster disease, the incidence of berry disease, and index of disease) were much lower in these grapevines grown using rain shelter technology than those grown in the open field during the fruit maturing process.

Papaya: Reddy and Gowda (2014) observed papaya plants free of papaya ringspot virus disease (PRSV) in greenhouse conditions until the end of the investigation period, while the incidence of open field PRSV occurred at 163.23 days with a 100 per cent incidence. Absence of disease may be due to the insect-proof net exclusion of viruliferous aphids.
Mango: Juntamanee (2013) investigated the impact of plastic roof on pre-harvest anthracnose disease and post-harvest anthracnose and fruit rot damage at ripening time. They found that the plastic roof significantly decreased the severity of the two most critical post-harvest diseases; anthracnose caused by Collectotrichum gloeosporioides at pre-harvest and ripening stages; and fruit rot caused by Lasiodiplodia theobromae at the ripening stage. Arauz (2000) reported that the incidence of anthracnose increased during the flowering season by continuous rainfall or by the moisture of more than 80 per cent.

Strawberry: Menzel et al. (2016) reported that about 2 per cent of the fruit under the tunnels was affected by rain, compared to about 10 per cent of the fruit under outdoor conditions. The average incidence of grey mould over the season was less than 1.5 per cent, but minor variations were observed in the incidence of grey mould (Botrytis) under outdoor conditions. Xiao et al. (2001) looked over 2 years at the effect of plastic tunnels on the incidence of fruit disease in strawberry plants in Florida. Two cultivars were cultivated in tunnels or outdoors with different fungicide schedules. The mean incidence of grey mould in tunnelgrowing plants was 88 to 94 per cent lower than in outdoor-growing plants. However, the Botrytis fruit rot incidence for the untreated control in tunnels was less than $2 \%$, which was $89 \%$ lower than that of the 7-day captan schedule in the field. This suggests that the use of the tunnel system will effectively regulate the Botrytis fruit rot without fungicide application.

\section{FUTURE PROSPECTS}

Nutritional security can only be ensured to the ever-increasing population of the country with the enhancement of fruit production at a faster rate. However, the area under fruit crops cannot be increased on such rate as the pressure on arable land due to the factors like urbanization, industrialization and other developmental activities. Therefore, it is the utmost necessity to improve the productivity of fruit crops with technological advancements like protected cultivation. Greenhouse cultivation of fruit crops has been on surge worldwide at a tremendous pace to ensure higher quality products in out of season and to combat inclement weather condition. However, in India, it is in the nascent stage and mainly concerted to strawberry. Now greenhouse cultivation of banana and papaya has also been started on a limited scale in certain pockets as both are short duration among fruit crops and further, due to delicacy in nature, both are highly affected by environmental adversaries (as low temperature, frost, hail storm, high wind, high temperature etc.) and insectpests. However, other fruit crops viz., grape, mango, peach, cherry, citrus, litchi etc. also has poten- 
tial to grow under greenhouse covers not only for quality and higher production but also to capture off-season markets. The foreign market can also be targeted with pesticide-free or with lesser pesticide load (under acceptable limits in international trade) with off-season production. There is a need to develop area-specific, most appropriate, efficient and affordable protected structures with cheaper and durable cladding materials (Paroda, 2014). Government support is highly required for the cultivation of protected fruit crops as they have long gestation period and the government should provide additional subsidy for growing perennial fruit crops to encourage on this due to higher initial investment and later returns as compared to flower and vegetable crops. With this technology, the fruit crops can also be grown in their nontraditional areas. With the concerted efforts of the centre and state governments, protected fruit cultivation is expected to gain popularity in India. Human resource development through training with the help of Indian Council of Agricultural Research (ICAR), various research centres and state agricultural universities (SAUs), various subsidy schemes and incentive programmes to the protected fruit growers will be highly beneficial, and need of the near future as protected cultivation is synonymously also known as future horticulture.

\section{Conclusion}

In the present era of pandemic and environmental fluctuations, promotion of greenhouse cultivation is inevitable for obtaining higher and quality production of any horticultural crop. However, fruit crops have the least area due to its perennial nature. But due to their nutritional values and increased round the year demands, they are now the potential crops for greenhouse cultivation. The government can provide additional financial support to the fruit growers under greenhouse as initial investment cost is a high and late return from perennial fruit crops as compared to other seasonal horticultural crops. Large-scale motivation and training of educated unemployed youths in the field of protected cultivation are also essential.

\section{REFERENCES}

1. Akinaga, T. and Hasbullah, R. (2002). Mango production using plastic greenhouse in Okinawa. Acta Horticulturae, 575: 745-749.

2. Allan, P. (2007). Phenology and production of Carica papaya 'Honey Gold' under cool subtropical conditions. Acta Horticulturae, 740: 217-224.

3. Arauz, L. F. (2000). Mango anthracnose: Economic impact and current options for integrated management. Plant Disease, 84: 600-611.

4. Beckmann, M. Z., Duarte De Paula, G. R. B., Gonzales-Mendes, V. A. and Piel, R. M. N. (2006). Solar radiation measured in protected ambient with tomato culture in summer-autumn seasons in Rio Grande do Sul State. Ciencia Rural, 36(1): 86-92.
5. Coban, H. (2004). The effects of plastic covering on yield and quality varieties of some table grapes in Alaşehir (Manisa). S.U. Ziraat Fakültesi Dergisi, 18: 101-103.

6. Darini, A. (2016). Investigation Banana Cultivars Yield and Quality traits under Green House Condition in Jiroft Region, Iran. Biological Forum - An International Journal, 8(1): 233-237.

7. Eckstein, K., Fraser, C. and Joubert, W. (1998) Greenhouse cultivation of bananas in South Africa. Acta Horticulturae, 490: 135-145.

8. Galan Sauco, V., Cabrera Cabrera, J., Hernandez Delgado, P. M. and Rodriguez Pastor, M. C. (1998). A comparison of protected and open-air cultivation of 'Grande Naine' and 'Dwarf Cavendish' bananas. Acta Horticulturae , 490: 247-259.

9. Ghosh, A. (2009). General idea of greenhouse technology. In: Greenhouse technology (The future concept of horticulture). Kalyani Publishers, New Delhi, pp 18-28.

10.Giaccone, M., Forlani, M. and Basile, B. (2012). Tree vigour, fruit yield and quality of nectarine trees grown under red photoselective anti-hail nets in southern Italy. Acta Horticulturae, 962: 287-293.

11.Gindaba, J. and Wand, S. J. E. (2007). Do fruit sunburn control measures affect leaf photosynthetic rate and stomatal conductance in 'Royal Gala' apple. Environmental and Experimnetal Botany, 59(2): 160-165.

12.Gubbuk, H. and Pekmezci, M. (2004). Comparison of open-field and protected cultivation of banana (Musa spp. AAA) in the coastal area of Turkey. New Zealand Journal of Crop and Horticultural Science, 32: 375-378.

13.Gubbuk, H., Pekmezci, M. and Erkan, M. (2004). Production potential of Cavendish cultivars (Musa spp. AAA) under greenhouse and field conditions in subtropical areas of Turkey. Soil and Plant Science, 54: 249-253.

14.Gunes, E. and Gubbuk, H. (2011). Growth, yield and fruit quality of three papaya cultivars grown under protected cultivation. Fruits, 67(1): 23-29.

15. Higuchi, H., Yonemoto, J. Y., Utsunomiya, N. and Sakuatani, T. (2001). Shading responses of cherimoya leaf chlorophyll content, leaf morphology, shoot growth, leaf gas exchange and fruit production under plastic house conditions. Environmental Control Biology, 39: 255-265.

16.Iglesias, I. and Alegre. S. (2006). The effect of antihail nets on fruit protection, radiation, temperature, quality and profitability of 'Mondial Gala' apples. Journal of Applied Horticulture, 8(2): 91-100.

17.Jiang-Fei, M., Peng-Fei, N., Teng-Fei, $X$. and ZhenWen, Z. (2013). Effect of rain-shelter cultivation of Vitis vinifera cv. Cabernet Gernischet on the phenolic profile of berry skins and the incidence of grape diseases. Molecules, 18: 381-397.

18.Junior, E. R. D., Boas, R. L. Y., Leonel, S., Cabrera, J. C. and Sauco, V. G. (2010). Quality of banana fruit produced in different locations (Greenhouse and Open Air) of the Canary Islands. Tree and Forestory Science and Biotechnology, 4(2): 11-14.

19.Juntamanee, K., Onnon, S., Yingjajaval, S. and Sangchote, S. (2013). Leaf photosynthesis and fruit quality of mango growing under field or plastic roof condition. Acta Horticulturae, 975: 415-420.

20.Kamiloglu, O., Polat, A. A. and Durgac, C. (2011) 
Comparison of open field and protected cultivation of five early table grape cultivars under Mediterranean conditions. Turkish Journal of Agriculture and Forestry, 35: 491-499.

21.Kaur, K. and Kaur, A. (2017). Papaya performance under various growing conditions cv. Red Lady 786 Agriculture Science Digest, 37(4): 290-293.

22.Larson, K. D., Daugovish, O. and Shaw, D. V. (2009). Optimizing strawberry production and fruit quality with use of protected culture in southern California. Acta Horticulturae, 842: 171-176.

23.Lionakis, S. M. and Loxou, B. K. (1997). Behaviour of some mango cultivars in the greenhouse under net and outdoors in the area of Chania Crete. Acta Horticulturae, 455: 401-406.

24.Lorente, M., Orts, J. V., Soler, E. and Capilla, M. A (2003). Economical and technical evaluation of various systems of protected cultivation for loquat. Options Me diterrane 'ennes Se 'ria A, Se 'minaries Me 'diterrane 'ens, No. 58, pp 147-150.

25.Medany, M. A., Abdrabbo, M. A. A., Farag, A. A., Hassanien, M. K. and Abou-Hadid, A. F. (2009). Growth and productivity of mango grown under greenhouse conditions. Egyptian Journal of Horticulture, 36(2): 373-382.

26.Menzel, C. M., Smith, L. A. and Moisander, J. A. (2016). Protected cropping of strawberry plants in subtropical Queensland. Acta Horticulturae, 1117: 273-278.

27.Mohamed, A. A. A. and Medany, M. A. (2015). Economic indicators of navel orange and keitt mango: comparison of net greenhouses vs. open field. International Journal of Development Research, 5(6): 4640-4644.

28.Novello, V., Tarricone, L., Vox, G. and De Palma, L. (2000). Effects of different plastic sheet coverings on microclimate and berry ripening of table grape cV. "Matilde". Journal of International Science Vigne Vin, 34: 49-55.

29.Pandey, S., Singh, J., Singh, S. K. and Mourya, I. B. (2015). Influence of growing environment on growth, yield and chemical composition of strawberry (Fragaria $\times$ ananassa) fruits under open vs naturally ventilated polyhouse conditions. Indian Journal of Agriculture Science, 85: 15401545.

30.Paroda, R.S. (2014). Strategies for promoting protected cultivation in India. In: Advances in Protected Cultivation (ed.). New India Publishing Agency, New Delhi, pp 1-9.

31.Polat, A. A., Durgac, C. and Caliskan, O. (2005). Effect of protected cultivation on the precocity, yield and fruit quality in loquat. Scientia Horticulture, 104 (2): 189-198.

32.Prakash, J., Singh, K., Goswami, A. K. and Singh, A. K. (2015). Comparison of plant growth, yield, fruit quality and biotic stress incidence in papaya var. Pusa Nanha under polyhouse and open field conditions. Indian Journal of Horticulture, 72(2): 183186.

33.Reddy, P. V. K. and Gowda V. N. (2014). Influence of greenhouse cultivation on fruit quality of 'Red Lady' papaya. Acta Horticulturae, 1024: 109-114.

34.Saxena, M. (2018). Horticulture Statistics at a Glance. Ministry of Agriculture and Farmers Welfare, Deptt. of Agriculture, Corporation and Farmers Welfare. Chandu Press, New Delhi.

35.Schettini, E., De Salvador, F. R., Scarascia Mugnozza, G. S. and Vox, G. (2011). Evaluation of coloured nets in peach protected cultivation. Acta Horticulturae, 893: 235-242.

36.Sen, F., Oksar, R. E. and Kesgin, M. (2016). Effects of shading and covering on 'Sultana Seedless' grape quality and storability. Journal of Agricultural Science and Technology, 18: 245-254.

37.Singh, Balraj. (2005). Protected structures, designs and fabrication. In: Protected cultivation of vegetable crops. Kalyani Publishers, New Delhi pp 13-36.

38.Singh, Brahma. (2014). DRDO- Harbinger of protected cultivation of vegetable crops in India. Chapter In: Advances in Protected Cultivation (ed.). New India Publishing Agency, New Delhi, pp 11-24.

39. Singh, V.P., Singh, P.K., Bhatt, Lalit, Maurya, S.K. and Jeena, A.S. (2013). Low cost protected structures for enhancing productivity and livelihood security of farming community of Uttarakhand hills- an overview. Progressive Research, 8(2): 155-159.

40.Singh, V.P., Singh, P.K. and Singh, C.P. (2017). Problems and prospects of greenhouse cultivation in fruit crops. In: Proceedings of $30^{\text {th }}$ National Convention of Agricultural Engineers \& National Seminar on 'Technological Innovations for Enhancing Profitability of Small and Marginal Farms' organized by Pantnagar Local Centre, The Institutions of Engineers (India) held on February 27-28, 2017, pp 188-193.

41.Tyagi, M., Singh, H. and Jawandha, S. K. (2015). Performance of papaya cultivars grown under protected conditions. Indian Journal of Horticulture, 72 (3):334-337.

42.Vool, E., Ratsep, K., Bachman, U. and Moor. (2014). The quality of grapes in open field and in protected cultivated condition. In: Proceedings of the International Conference "Horticulture in quality and culture of life". pp 839-846.

43.Vukovic, M., Brkljaca, M., Rumora, J., Fruk, M., Jatoi, M. A., Jemric, T. (2017). Vegetative and reproductive traits of young peaches and nectarines grown under red photoselective net. ACS - Agriculturae Conspectus Scientificus, 81(3): 181-185.

44.Weber, C. A., Maloney, K. E. and Sanford, J. C. (2004). Long-term field performance of primocane fruiting raspberry cultivars in New York. Hort Technology, 14(4): 590-593.

45.Xiao, C. L., Chandler, C. K., Price, J. F., Duval, J. R., Mertely, J. C. and Legard, D. E. (2001). Comparison of epidemics of Botrytis fruit rot and powdery mildew of strawberry in large plastic tunnel and field production systems. Plant Disease, 85: 901-909.

46.Young, R. E., McMahon, M. J., Rajapakse, N. C., Decoteau, D. R. (1994). Spectral filtering for plant production. International Lighting in Controlled Environments Workshop, NASA- CP- 95- 3309. 